\title{
ANTIDIABETIC ACTIVITY OF OKRA (Abelmoschus esculentus L.) FRUIT EXTRACT
}

\author{
W. Aligita ${ }^{1, *}$, S. Muhsinin ${ }^{1}$, E. Susilawati ${ }^{1}$, Dahliaa ${ }^{1}$, D.S. Pratiwi ${ }^{1}$, D. \\ Aprilliani $^{1}$, A. Artarini ${ }^{2}$ and I.K. Adnyana ${ }^{2}$ \\ ${ }^{1}$ Bandung School of Pharmacy, Bandung, Indonesia \\ ${ }^{2}$ School of Pharmacy, Bandung Institute of Technology, Bandung, Indonesia \\ *E-mail :w.aligita@gmail.com
}

\begin{abstract}
Diabetes mellitus is a heterogeneous group of disorders characterized by increasing blood glucose level caused by lack of insulin hormone. One of the plants that were often used as traditional medicine for diabetes in Indonesia was okra (Abelmoschus esculentus L.) fruit. The aim of this research was to evaluate the antidiabetes activity of okra fruit extract. The study was divided into several steps: a preliminary study of anthyperglycemia of okra fruit after glucose, sucrose, and amylum administration; antidiabetic activity in insulin deficiency animal model developed by aloxan administration and insulin resistance animal model developed by lipid emulsion administration, and in vitro study of $\alpha$-glucosidase and $\alpha$-amylase enzyme inhibition activity. The result showed that the extract group had antihyperglycemia activity after glucose, sucrose, and amylum administration. In insulin deficiency animal model, glibenclamide and extract could decrease blood glucose level. In insulin resistance animal, metformin and extract could increase constantly of insulin tolerance test. From the $\alpha$-glucosidase inhibition activity, it was known the acarbose's $\mathrm{IC}_{50}$ was $44.374 \mu \mathrm{g} / \mathrm{mL}$, while okra fruit extract was $1533.742 \mu \mathrm{g} / \mathrm{mL}$. And the $\mathrm{IC}_{50}$ value of acarbose to $\alpha$-amylase enzyme was $46.821 \mu \mathrm{g} / \mathrm{mL}$, while okra fruit extract was $1228.469 \mu \mathrm{g} / \mathrm{mL}$. In conclusion, okra (Abelmoschus esculentus L.) fruit extract with a dose of $50 \mathrm{mg} / \mathrm{kg}$ bw had the antidiabetic activity with the mechanism of action by increasing insulin secretion, increasing insulin sensitivity, and inhibiting carbohydrate absorption in the intestine; but couldn't inhibit alpha-glucosidase and alpha-amylase enzyme.

Keywords: Abelmoschus esculentus L., diabetes mellitus, insulin deficiency, insulin resistance, okra fruit

(C) RASĀYAN. All rights reserved
\end{abstract}

\section{INTRODUCTION}

Diabetes mellitus (DM) is a group of metabolic disorders characterized by hyperglycemia and disorders of carbohydrate, fat and protein metabolism ${ }^{1}$. DM is ranked 6th as the cause of death in the world. About 1.3 million people die from diabetes and 4\% die before the age of 70. By 2030 it has been estimated that DM ranks 7th in the world cause of death. According to the International Diabetes Federation, more than 371 million people in the world who have 20-79 years have diabetes ${ }^{2}$. In Indonesia, it is estimated that by 2030 there will be 21.3 million people with DM. Indonesia ranks 7th in the highest prevalence of diabetes, after China, India, America, Brazil, Russia and Mexico. Diabetes mellitus is a group of symptoms that arise due to an increase in blood glucose levels caused by decreasing in insulin secretion progressively ${ }^{1}$. These can be caused by a decrease in insulin secretion, a decrease in insulin sensitivity, or both $^{3}$.

The main categories of types of diabetes mellitus are Type- 1 and Type- 2 diabetes. Type- 1 diabetes is characterized by insufficient insulin production, while type 2 diabetes is caused by a lack of optimal use of insulin produced by the body. Type- 2 diabetes is $90 \%$ of cases that are often found in all diabetes ${ }^{2}$.

Based on the high prevalence of diabetes mellitus, treatment and maintenance in diabetes mellitus are very important, both with drugs (pharmacological therapy) and without drugs (non-pharmacological therapy). Nonpharmacological therapy can be done in several ways, but in general by changing the pattern of life for the better such as medical nutrition therapy, a balanced diet with a balanced meal plan between carbohydrates with low-saturated fat foods, maintaining weight, calorie restriction, and exercise

Rasayan J. Chem., 12(1), 157-167(2019)

http://dx.doi.org/10.31788/RJC.2019.1215059

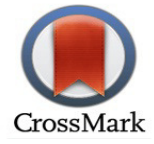


to increase sensitivity insulin and control blood sugar levels. Whereas pharmacological therapy can be given insulin therapy and oral hypoglycemic drugs in helping glucose control in the maintenance of diabetes mellitus ${ }^{4}$. Oral hypoglycemic drugs can cause a number of side effects such as gastrointestinal disorders, dizziness, hypoglycemia, and decreased appetite. Therefore we need a drug with an antidiabetic activity that is safer, more comfortable and economical with lighter side effects.

Treatment of diabetes until now is still symptomatic and must be carried out for life, potentially causing various side effects such as hypoglycemic, headache, vomit, emesis, and symptoms in gastrointestinal ${ }^{5}$. Nutrition therapy is one of the solutions that can be used to maintain the blood glucose levels of diabetics in the normal range. The American Diabetes Association states that nutrition therapy is an important point for diabetic patients, especially in the prevention of type 2 diabetes and slowing its progression. Indonesia is also a country that has very high biodiversity, and there is still a lot of potential from the flora of this country that has not been explored and developed as an alternative nutritional therapy. The plant that had the potential to be used as nutritional therapy for diabetics was okra fruit (Abelmoschus esculentus L.).

Okra (Abelmoschus esculentus (L.) Moench) is one of the most widely known and utilized malvaceae family species. Okra is traditionally used not only as a vegetable but is also used for herbal therapy. In traditional medicine in India, okra plants are usually used in the form of infusions. In Indonesia, empirical use of okra is by cutting the fruit into approximately $3 \mathrm{~cm}$ long pieces. Then the okra is boiled without peeling the skin in two glasses of water until boiling and the boiled water is then drunk.

Various activity evaluation had been carried out on okra fruit. As a result, okra fruit had antioxidant activity $^{6,7}$. The study showed that antioxidant could prevent the prevalence of metabolic syndrome and most of the vegetables and fruit were rich with it ${ }^{8,9}$. Okra extract also had activity as an invitro nonenzymatic lipid inhibitor ${ }^{10}$. The skin and okra seed powder contained significant antioxidant properties in diabetic rats induced streptozotocin.

In okra flowers found the highest number of compounds, that were phenolics and flavonoids ${ }^{11}$. Okra had a high fiber content, which helps stabilize blood sugar by regulating the rate of sugar absorbed from the intestinal tract. Because of these fiber and other nutrients, okra had activity in minimizing blood sugar levels in diabetics. This fiber also helps maintain blood sugar levels only by slowing the absorption of sugar through the intestine ${ }^{12}$. In the previous studies, okra extract with a dose of $100 \mathrm{mg} / \mathrm{kg}$ bw was effective in reducing blood glucose levels in rats induced by alloxan and streptozotocin ${ }^{13,142}$.

Okra fruit also showed activity in preventing kidney disease. In the study, people who consumed okra every day reduced the clinical indication of kidney damage significantly. Kidney damage is often associated with diabetes, because almost $50 \%$ of cases of kidney disease are caused by diabetes ${ }^{15}$. Okra could be used to treat digestive problems. Polysaccharides in okra pods had anti-adhesive properties strong enough to reduce the attachment between bacteria and gastric tissue. Therefore, okra was very effective in treating gastric ulcers because it could inhibit the adhesion of Helicobacter pylori, a gastric ulcer-causing bacterium ${ }^{16}$. Besides for its pharmacological property, okra can also be used as a low-cost natural absorbent technology for water treatment ${ }^{17}$.

Based on literature studies, it could be seen that okra fruit had antidiabetic potential, although the mechanism of action of okra fruit as an antidiabetic was not yet fully known. In this study, experiments would be conducted on okra fruit extract as antidiabetic using in vitro and in vivo methods. In vitro experiment included inhibition of alpha glucosidase and alpha amylase enzymes, while in vivo experiments included evaluation of antihyperglycemia after administration of several carbohydrates and antidiabetic evaluation in insulin deficiency and insulin resistance animal model. The data obtained from this experiment was expected to provide an overview of the mechanism of action of okra fruit extract as antidiabetic.

\section{Identification and Authentication of Plant Material}

\section{EXPERIMENTAL}

Okra (Abelmoschus esculentus L.) fruit was obtained from Research Station for Spices and Medicinal Plants, Bogor, West Java, Indonesia. The plant identification and authentication were performed by Center for Plant Conservation Botanic Gardens, Bogor, West Java, Indonesia. 
RASĀYAN J. Chem.

Vol. 12 | No. 1 |157 - 167| January - March | 2019

\title{
Preparation of Abelmoschus esculentus L. Extract
}

Okra fruit was cleaned and cut into pieces, then mashed using a blender with enough water. The mixture was filtered using a filter paper and the filtrate was concentrated using freeze drier.

\begin{abstract}
Animals
Male Swiss-Webster mice 2-3 months old weighing 20-30 g were kept at standard laboratory conditions at $24-26^{\circ} \mathrm{C}$, humidity $70-75 \%$, and 12 hours light/dark cycle. Animals were fed with standard chow and water ad libitum. The methods in this study were performed in accordance with ethics and guide for animals care and used. Ethical approval was published by the Ethics Committee Padjajaran University with registration number 0818020269.
\end{abstract}

\section{General Procedure}

Antiperglycemic Evaluation as a Preliminary Study

Before the commencement of the experiment and after first stage induction using high carbohydrate diet, an oral glucose tolerance test (OGTT) using glucose $3 \mathrm{~g} / \mathrm{kg}$ bw was performed after a 12-hour fasting period. Blood glucose concentration from the tail vein was measured using the Easy Touch® blood glucose meter at 0 and 30,60, 90 and 120 min after glucose administration ${ }^{18}$. The modification of this method was also performed by replacing the glucose with sucrose or starch.

\section{In-vivo Antidiabetic Evaluation of Okra Fruit Extract in Insulin Deficiency Animal Model}

There were two stages in this experiment, the first one was the induction phase and the second was the treatment phase. In the first phase, mice were induced with alloxan $50 \mathrm{mg} / \mathrm{kg}$ bw intravenously ${ }^{19}$. Mice with hyperglycemia (blood glucose $>200 \mathrm{mg} / \mathrm{dL}$ ) would be used in the second phase of evaluation. Mice were randomly divided into 7 groups: negative control group, the positive control group, standard drug group (glibenclamide $0.65 \mathrm{mg} / \mathrm{kg} \mathrm{bw}$ ), and extract groups at a dose of $25 \mathrm{mg} / \mathrm{kg} \mathrm{bw}, 50 \mathrm{mg} / \mathrm{kg} \mathrm{bw}, 100$ $\mathrm{mg} / \mathrm{kg}$, and $200 \mathrm{mg} / \mathrm{kg}$ bw. Administration of extracts and glibenclamide as a standard drug were performed for 14 days. Parameters measured were blood glucose levels on days 3, 7, 11 and 14 during treatment. Mice blood was taken from the vein part of the tail and measured using EasyTouch ${ }^{\circledR}$ glucometer. The data were then analyzed statistically using ANOVA method.

\section{In-vivo Antidiabetic Evaluation of Okra Fruit Extract in Insulin Resistance Animal Model}

There were two stages in this evaluation, the first one was the induction phase and the second was the treatment phase. In the first phase, mice were induced using lipid emulsion at a dose of $0.42 \mathrm{ml} / 20 \mathrm{~g} \mathrm{bw}$ for 2 weeks ${ }^{19}$. After mice developed to insulin resistance condition, the experiment stepped to the second phase of evaluation. Mice were randomly grouped into 7 groups: negative control group, the positive control group, standard drug group (metformin $135 \mathrm{mg} / \mathrm{kg} \mathrm{bw}$ ), and extract groups at a dose of $25 \mathrm{mg} / \mathrm{kg}$ bw, $50 \mathrm{mg} / \mathrm{kg} \mathrm{bw}, 100 \mathrm{mg} / \mathrm{kg}$, and $200 \mathrm{mg} / \mathrm{kg}$ bw. Administration of extracts and metformin as a standard drug were performed for 14 days. Parameters measured were insulin sensitivity, expressed by a constant of insulin tolerance test, before induction, after induction and after treatment using insulin tolerance test. The data were then analyzed statistically using ANOVA method.

\section{Insulin Tolerance Test}

An insulin tolerance test (ITT) was performed using insulin $0.75 \mathrm{U} / \mathrm{kg} \mathrm{bw}$, intraperitoneally. Blood glucose concentration from the tail vein was measured using the Easy Touch ${ }^{\circledR}$ blood glucose meter at 0 , $15,30,45$, and 60 minutes after insulin administration ${ }^{19}$. Insulin tolerance level was expressed in a constant of insulin tolerance test.

\section{In-vitro Study of the Alpha Glucosidase and Alpha Amylase Enzyme Inhibition Activity Alpha Amylase Enzyme Inhibition Activity}

$\alpha$-amylase inhibitor activity was carried out according to Elya et al. ${ }^{20}$ with slight modification. $25 \mu \mathrm{L}$ sample (acarbose or okra fruit extract) of varying concentrations were added to $75 \mu \mathrm{L}$ of $0.5 \mathrm{U} / \mathrm{ml}$ of $\alpha$ glucosidase in phosphate buffer $\mathrm{pH} 6.8$ solution and were incubated at $37^{\circ} \mathrm{C}$ for $15 \mathrm{~min}$. Then $25 \mu \mathrm{L}$ 
pNPG was added to each reaction well and incubated at $37^{\circ} \mathrm{C}$ for $15 \mathrm{~min} .150 \mu \mathrm{L} \mathrm{Na}_{2} \mathrm{CO}_{3}$ was added to stop the enzymatic reaction. The absorbance was read at $405 \mathrm{~nm}$. The control reaction representing 100\% enzyme activity did not contain any plant extract. To eliminate the absorbance produced by plant extract, appropriate extract controls without the enzyme were also included. Inhibition of enzyme activity was calculated as:

Inhibition of enzyme activity $(\%)=(\mathrm{C}-\mathrm{S}) / \mathrm{C} \times 100$,

Where, $\mathrm{S}$ is the absorbance of the sample and $\mathrm{C}$ is the absorbance of blank (no extract).

Table-1: Blood Glucose Level after Glucose Administration

\begin{tabular}{|l|c|c|c|c|c|c|}
\hline \multirow{2}{*}{\multicolumn{1}{c|}{ Group }} & \multicolumn{6}{c|}{ Blood glucose level at minutes- (mg/dl) } \\
\cline { 2 - 7 } & $\mathbf{0}$ & $\mathbf{3 0}$ & $\mathbf{6 0}$ & $\mathbf{9 0}$ & $\mathbf{1 2 0}$ & $\mathbf{1 5 0}$ \\
\hline Negative control & $95 \pm 3$ & $103 \pm 2^{*}$ & $90 \pm 5^{*}$ & $76 \pm 1^{*}$ & $71 \pm 1^{*}$ & $80 \pm 11^{*}$ \\
\hline Positive control & $91 \pm 3$ & $207 \pm 58$ & $165 \pm 6$ & $147 \pm 13$ & $129 \pm 10$ & $118 \pm 23$ \\
\hline Glibenclamide 0.65 mg/kg bw & $89 \pm 13$ & $98 \pm 1^{*}$ & $87 \pm 7^{*}$ & $66 \pm 9^{*}$ & $65 \pm 10^{*}$ & $65 \pm 18^{*}$ \\
\hline OFE 25 mg/kg bw & $90 \pm 5$ & $127 \pm 1^{*}$ & $109 \pm 16^{*}$ & $106 \pm 25^{*} \#$ & $85 \pm 5^{*}$ & $79 \pm 10^{*}$ \\
\hline OFE 50 mg/kg bw & $80 \pm 9$ & $98 \pm 40^{*}$ & $97 \pm 33^{*}$ & $89 \pm 23^{*}$ & $75 \pm 19^{*}$ & $74 \pm 19^{*}$ \\
\hline OFE 100 mg/kg bw & $80 \pm 9$ & $149 \pm 43$ & $102 \pm 37^{*}$ & $86 \pm 24^{*}$ & $88 \pm 41^{*}$ & $76 \pm 36^{*}$ \\
\hline OFE 200 mg/kg bw & $84 \pm 4$ & $153 \pm 37$ & $105 \pm 17^{*}$ & $93 \pm 15^{*}$ & $66 \pm 20^{*}$ & $61 \pm 14^{*}$ \\
\hline
\end{tabular}

Note: Data are presented as mean $\pm \mathrm{SD}$, * means significantly different compared to the positive control group, OFE means okra fruit extract, $\mathrm{p}<0.05, \mathrm{n}=3$ mice/group.

\section{Alpha Amylase Enzyme Inhibition Activity}

$\alpha$-amylase inhibitor activity was carried out according to Xiao et al. ${ }^{21}$ with slight modification based on the starch-iodine test. $1 \mathrm{ml}$ sample (acarbose or okra fruit extract) of varying concentrations were added to $1 \mathrm{ml}$ of $0.5 \mathrm{U} / \mathrm{ml}$ of $\alpha$-amylase in phosphate buffer $\mathrm{pH} 6.8$ solution and were incubated at $37^{\circ} \mathrm{C}$ for 30 min. Then $1 \mathrm{ml}$ soluble starch $(1 \%, \mathrm{w} / \mathrm{v})$ was added to each reaction well and incubated at $37^{\circ} \mathrm{C}$ for $3 \mathrm{~min}$. $500 \mu \mathrm{L} \mathrm{HCl} 1 \mathrm{M}$ was added to stop the enzymatic reaction, followed by the addition of $500 \mu \mathrm{L}$ of iodine reagent. The absorbance was read at $620 \mathrm{~nm}$. The control reaction representing 100\% enzyme activity did not contain any plant extract. To eliminate the absorbance produced by plant extract, appropriate extract controls without the enzyme were also included. Inhibition of enzyme activity was calculated using the same formula as $\alpha$-glucosidase enzyme inhibition activity.

\section{RESULTS AND DISCUSSION}

From the results of this experiment, the following data were obtained: profiles of blood glucose levels in normal animals after administration of glucose, sucrose, and starch; profile of blood glucose levels in animal models of insulin deficiency for 14 days of treatment; profile of blood glucose levels in animal models of insulin resistance for 14 days of treatment; and IC50 values of the inhibition of alpha glucosidase and alpha amylase enzymes.

\section{Preliminary Study}

Oral glucose tolerance test is a preliminary test conducted to determine the potential of okra fruit juice as antidiabetic. Blood glucose profile during evaluation was shown in Table-1.

From the data in Table-1, it could be seen that there was an increase in blood glucose level in each test group except the negative control group. This showed that there had been a glucose absorption process which caused an increase in blood glucose level. The glibenclamide group did not show significant differences ( $p>0.05)$ compared to negative controls at 30 minutes, which means that glibenclamide as an antidiabetic standard drug could reduce blood glucose level back to normal with less than 30 minutes onset. Okra fruit juice at a dose of $25 \mathrm{mg} / \mathrm{kg} \mathrm{BW}$ and $50 \mathrm{mg} / \mathrm{kg} \mathrm{BW}$ had been able to reduce blood glucose level at 30 minutes indicated by a significant difference $(\mathrm{p}<0.05)$ to positive control group, and its activity was proportional to glibenclamide indicated by no difference statistically compared to the 
glibenclamide group. While okra fruit juice at $100 \mathrm{mg} / \mathrm{kg}$ bw and $200 \mathrm{mg} / \mathrm{kg}$ bw could significantly reduce blood glucose level compared to the positive control group $(p<0.05)$ at 60 minutes. Based on the profile of blood glucose levels in the oral glucose tolerance test, okra fruit juice had the activity to reduce blood glucose levels at doses of 25, 50,100, and $200 \mathrm{mg} / \mathrm{kg}$ bw in normal animals, so it was concluded that it had antidiabetic potential.

Furthermore, modification of the oral glucose tolerance test method was performed by replacing glucose with sucrose or starch. Sucrose is a disaccharide formed from glucose and fructose as the monomer. The process of hydrolysis of sucrose into the monomer is carried out by the enzyme $\alpha$-glucosidase. So, this procedure can provide an overview of carbohydrate absorption activity, especially sucrose. Profile of blood glucose level after sucrose administration was shown in Table-2.

Table-2: Blood Glucose Level Profile after Sucrose Administration

\begin{tabular}{|l|c|c|c|c|c|c|c|}
\hline \multirow{2}{*}{\multicolumn{1}{c|}{ Group }} & \multicolumn{7}{c|}{ Blood glucose level at minutes- (mg/dl) } \\
\cline { 2 - 8 } & $\mathbf{0}$ & $\mathbf{3 0}$ & $\mathbf{6 0}$ & $\mathbf{9 0}$ & $\mathbf{1 2 0}$ & $\mathbf{1 5 0}$ & $\mathbf{1 8 0}$ \\
\hline Negative control & $86 \pm 10$ & $90 \pm 8^{*}$ & $91 \pm 12^{*}$ & $86 \pm 15^{*}$ & $81 \pm 8^{*}$ & $83 \pm 9$ & $75 \pm 10^{*}$ \\
\hline Positive control & $94 \pm 9$ & $154 \pm 5$ & $131 \pm 22$ & $118 \pm 9$ & $112 \pm 10$ & $103 \pm 10$ & $99 \pm 8$ \\
\hline Acarbose 0.65 mg/kg bw & $84 \pm 13$ & $103 \pm 23^{*}$ & $91 \pm 18^{*}$ & $87 \pm 16^{*}$ & $85 \pm 12^{*}$ & $81 \pm 19$ & $86 \pm 14$ \\
\hline OFE 25 mg/kg bw & $93 \pm 10$ & $147 \pm 20 \#$ & $121 \pm 6 \#$ & $110 \pm 13$ & $96 \pm 14$ & $90 \pm 16$ & $85 \pm 10$ \\
\hline OFE 50 mg/kg bw & $91 \pm 13$ & $143 \pm 24 \#$ & $122 \pm 15 \#$ & $113 \pm 18$ & $106 \pm 17 \#$ & $99 \pm 20$ & $90 \pm 17$ \\
\hline OFE 100 mg/kg bw & $87 \pm 15$ & $124 \pm 23$ & $96 \pm 12^{*}$ & $84 \pm 15^{*}$ & $85 \pm 11^{*}$ & $76 \pm 12$ & $68 \pm 11^{*}$ \\
\hline OFE 200 mg/kg bw & $92 \pm 10$ & $139 \pm 53$ & $113 \pm 37$ & $105 \pm 39$ & $97 \pm 19$ & $90 \pm 31$ & $89 \pm 29$ \\
\hline
\end{tabular}

Note: Data are presented as mean $\pm \mathrm{SD}, *$ means significantly different compared to the positive control group, \# means significantly different compared to the acarbose group, OFE means okra fruit extract, $\mathrm{p}<0.05, \mathrm{n}=4$ mice/group.

From the data in Table-2, it could be seen that 30 minutes after sucrose administration, the positive control group showed a significant difference $(\mathrm{P}<0.05)$ compared to the negative control group. This showed that the administration of sucrose could increase blood glucose level, which means that there had been a process of hydrolysis of disaccharides into glucose and glucose absorption. The group given acarbose as a standard drug showed a significant decrease in blood glucose level $(p<0.05)$ during the evaluation period compared to positive control group. This was in line with the mechanism of action of the acarbose which had the ability to slow down the absorption of glucose in the small intestine, so that it had the effect of lowering blood glucose level after meals. In the group administered okra fruit extract, the dose that showed a significant difference with the positive control group during the evaluation period was a dose of $100 \mathrm{mg} / \mathrm{kg}$ bw. A significant decrease in blood glucose levels occurred starting from 60 minutes after administration of sucrose. This group of $100 \mathrm{mg} / \mathrm{kg}$ bw okra extract also showed no significant difference with the acarbose group, which means that the activity was comparable to acarbose. This result showed that okra fruit extract at a dose of $100 \mathrm{mg} / \mathrm{kg}$ bw could inhibit glucose absorption after sucrose administration.

Modification of the method of oral glucose tolerance test was also performed by replacing glucose with starch. The starch is a polysaccharide or carbohydrate composed of hundreds or even thousands of monosaccharides that are linked by glycosidic bonds. In order for this polysaccharide to be absorbed, enzymes are needed, one of which is the $\alpha$-amylase enzyme which functions to hydrolyze complex polysaccharides into oligosaccharides and disaccharides. Profile of blood glucose levels due to the administration of starch is shown in Table-3.

Based on Table-3, it could be seen that 90 minutes after administration of starch, the positive control group experienced a significant increase in blood glucose level $(\mathrm{P}<0.05)$ compared to the negative control group. This showed that the starch administered had been hydrolyzed by the enzyme to glucose and then absorbed. The group treated with acarbose showed a significantly different blood glucose level compared to the positive control group in the 90th minute. Whereas in the group given okra fruit extract, activities comparable to acarbose were shown by extracts at a dose of $50 \mathrm{mg} / \mathrm{kgBB}$ and $100 \mathrm{mg} / \mathrm{kg} \mathrm{bw}$. 
RASĀYAN J. Chem.

Vol. 12 | No. 1 |157 - 167| January - March | 2019

This can be seen from the blood glucose levels of the two groups which were significantly different compared to the positive control group and there were no significant differences with the acarbose group.

Table-3: Blood Glucose Level Profile after Starch Administration

\begin{tabular}{|l|c|c|c|c|c|c}
\hline \multirow{2}{*}{\multicolumn{1}{c|}{ Group }} & \multicolumn{7}{c}{ Blood glucose level at minutes- (mg/dl) } \\
\cline { 2 - 7 } & $\mathbf{0}$ & $\mathbf{9 0}$ & $\mathbf{1 2 0}$ & $\mathbf{1 5 0}$ & $\mathbf{1 8 0}$ & $\mathbf{2 1 0}$ \\
\hline Negative control & $87 \pm 3$ & $77 \pm 12^{*}$ & $84 \pm 8^{*}$ & $84 \pm 6$ & $82 \pm 6$ & $71 \pm 1$ \\
\hline Positive control & $88 \pm 13$ & $133 \pm 5 \#$ & $137 \pm 11 \#$ & $125 \pm 14$ & $113 \pm 13$ & $86 \pm 4$ \\
\hline Acarbose 0.65 mg/kg bw & $87 \pm 12$ & $90 \pm 23^{*}$ & $94 \pm 31 *$ & $82 \pm 20$ & $80 \pm 18$ & $71 \pm 16$ \\
\hline OFE 25 mg/kg bw & $84 \pm 3$ & $129 \pm 14 \#$ & $119 \pm 19$ & $101 \pm 22$ & $91 \pm 26$ & $80 \pm 10$ \\
\hline OFE 50 mg/kg bw & $86 \pm 8$ & $109 \pm 1$ & $101 \pm 9$ & $101 \pm 27$ & $84 \pm 10$ & $76 \pm 6$ \\
\hline OFE $100 \mathrm{mg} / \mathrm{kg}$ bw & $85 \pm 13$ & $108 \pm 28$ & $98 \pm 18$ & $93 \pm 17$ & $87 \pm 11$ & $79 \pm 7$ \\
\hline OFE 200 mg/kg bw & $88 \pm 10$ & $128 \pm 11$ & $108 \pm 3$ & $97 \pm 11$ & $83 \pm 1$ & $77 \pm 6$ \\
\hline
\end{tabular}

Note: Data are presented as mean $\pm \mathrm{SD}, *$ means significantly different compared to the positive control group, \# means significantly different compared to the acarbose group, OFE means okra fruit extract, $\mathrm{p}<0.05, \mathrm{n}=4$ mice/group.

\section{Antidiabetic Activity on Insulin Deficiency Animal Model}

Modeling of insulin-deficient animals was carried out by injecting alloxan monohydrate at a dose of 55$60 \mathrm{mg} / \mathrm{kgBW}$ intravenously. Alloxan injection was diabetogenic because it could selectively cause pancreatic $\beta$ cell damage which ultimately resulted in a decrease in insulin secretion resulting in an increase in blood glucose levels. The mechanism of alloxan in causing diabetes mellitus was by oxidizing sulphydryl groups, inhibiting glucokinase enzymes, producing free radicals, and disrupting intracellular calcium homeostasis. ${ }^{22,23}$ The selectivity of alloxan to pancreatic $\beta$ cells is due to the similarity of structures with glucose which resulted in the mechanism of alloxan uptake by pancreatic $\beta$ cells to be highly efficient. ${ }^{24}$ The development of diabetes conditions was evaluated on the third day after induction. The parameters measured were fasting blood glucose levels using Easy Touch ${ }^{\circledR}$ glucometer. The animals used for further evaluation were those who had fasting blood glucose levels $\geq 200 \mathrm{mg} / \mathrm{dL}$. Mice were divided into seven groups randomly: negative control group, positive control group, glibenclamide group dose $0.65 \mathrm{mg} / \mathrm{kgBW}$ as a standard drug group, okra fruit juice group dose $25 \mathrm{mg} / \mathrm{kgBW}$, jus fruit okra group dose $50 \mathrm{mg} / \mathrm{kgBW}$, okra fruit juice group dose $100 \mathrm{mg} / \mathrm{kgBW}$, and okra fruit juice group dose $200 \mathrm{mg} / \mathrm{kgBW}$. Therapy for each group was given for 14 days orally. Measurement of fasting blood glucose levels was carried out on days 3, 7, 11, and 14 treatments. Profile of blood glucose levels during therapy could be seen in Fig.-1.

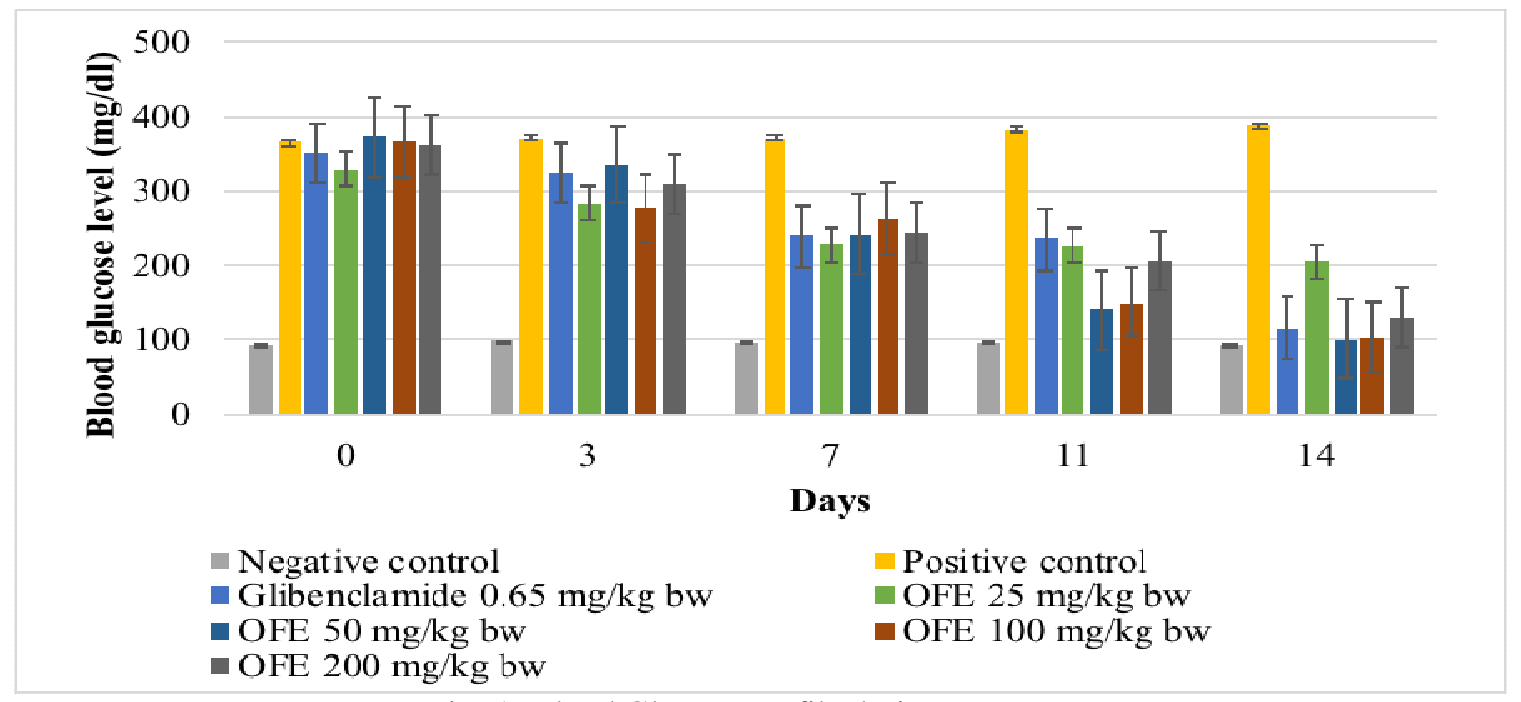

Fig.-1: Blood Glucose Profile during Treatment 
Figure-1 showed that induction using alloxan could increase blood glucose level. It was seen from the increase in blood glucose level experienced by all groups except the negative control group on day 0 treatment. The decrease in blood glucose level on the 3rd day until the 14th day was shown by the glibenclamide group and all groups of okra fruit juice at doses of $25,50,100$, and $200 \mathrm{mg} / \mathrm{kg} \mathrm{BW}$. The decrease in blood glucose level in the glibenclamide group as a standard drug for the treatment of diabetes was caused by the ability of glibenclamide to increase insulin secretion by pancreatic $\beta$ cells ${ }^{1}$.

Table-4: Blood Glucose Level on Insulin Deficiency Animal Model

\begin{tabular}{lccccc}
\hline \multirow{2}{*}{ Group } & \multicolumn{5}{c}{ Blood glucose level at days- (mg/dl) } \\
\cline { 2 - 6 } & $\mathbf{0}$ & $\mathbf{3}$ & $\mathbf{7}$ & $\mathbf{1 1}$ & $\mathbf{1 4}$ \\
\hline Negative control & $93 \pm 5^{* \#}$ & $98 \pm 8^{* \#}$ & $97 \pm 13^{* \#}$ & $97 \pm 15^{*} \#$ & $94 \pm 8^{*}$ \\
\cline { 2 - 6 } Positive control & $365 \pm 43$ & $372 \pm 39$ & $371 \pm 25$ & $382 \pm 36 \#$ & $388 \pm 68 \#$ \\
Glibenclamide $0.65 \mathrm{mg} / \mathrm{kg}$ bw & $351 \pm 82$ & $325 \pm 64$ & $239 \pm 66^{*}$ & $235 \pm 96^{*}$ & $116 \pm 22^{*}$ \\
\cline { 2 - 6 } OFE 25 mg/kg bw & $329 \pm 101$ & $283 \pm 92$ & $228 \pm 136^{*}$ & $227 \pm 158^{*}$ & $205 \pm 156^{*}$ \\
OFE 50 mg/kg bw & $372 \pm 69$ & $336 \pm 92$ & $242 \pm 74^{*}$ & $141 \pm 37^{*}$ & $101 \pm 6^{*}$ \\
OFE 100 mg/kg bw & $366 \pm 95$ & $278 \pm 126$ & $263 \pm 119$ & $151 \pm 57^{*}$ & $104 \pm 15^{*}$ \\
OFE 200 mg/kg bw & $362 \pm 131$ & $311 \pm 37$ & $246 \pm 62^{*}$ & $207 \pm 69^{*}$ & $130 \pm 17^{*}$ \\
\hline
\end{tabular}

Note: Data are presented as mean $\pm \mathrm{SD}, *$ means significantly different compared to the positive control group, \# means significantly different compared to the glibenclamide group, OFE means okra fruit extract, $\mathrm{p}<0.05, \mathrm{n}=4$ mice/group.

Table-4 showed that all groups were given glibenclamide or okra fruit juice at doses of 25, 50, 100 and $200 \mathrm{mg} / \mathrm{kg}$ bw showed a decrease in blood glucose levels from day 3, although it was not statistically significant compared to the positive control group. This means that the extract of okra fruit water at all doses had the potential to reduce blood glucose level. Significant differences were only shown on the seventh day of therapy by the glibenclamide group and the okra fruit juice group at doses of 25, 50 and $200 \mathrm{mg} / \mathrm{kg} \mathrm{bw}$; while the group of okra fruit juice with a dose of $100 \mathrm{mg} / \mathrm{kg}$ bw showed a significant difference to the positive control group $(\mathrm{p}<0.05)$ on the 10th day. Until the 14th day of therapy, all groups of okra fruit juice experienced a significant decrease in blood glucose levels compared to the positive control group, except that the group of okra fruit juice at a dose of $25 \mathrm{mg} / \mathrm{kg}$ bw showed a significant difference when compared to the glibenclamide group.

This means that the activity of okra fruit juice at a dose of $25 \mathrm{mg} / \mathrm{kg}$ bw in reducing blood glucose levels was not as good as glibenclamide.

Determination of the effective dose of okra fruit juice could be seen from the percentage of decrease in blood glucose level on day 14 where the negative control group and positive control did not experience a decrease in blood glucose level, while all groups were given glibenclamide or okra fruit juice experienced a decrease in blood glucose level. The decrease in blood glucose level in the glibenclamide group was $67 \%$, and a decrease in blood glucose level in okra fruit extract at dose of $25,50,100$, and $200 \mathrm{mg} / \mathrm{kg}$ bw was $38 \%, 73 \%, 72 \%$, and $64 \%$, respectively. Based on the percentage value of a decrease in blood glucose levels, it could be seen that the most equal value to glibenclamide was shown by okra fruit juice at a dose of $50 \mathrm{mg} / \mathrm{kg}$ bw.

\section{Antidiabetic Activity On Insulin Resistance Animal Model}

Induction of animal models of insulin resistance was performed by administrating lipomed orally with a dose of $0.42 \mathrm{~mL} / 20 \mathrm{~g}$ bw for 14 days. A high amount of fat could cause a decrease in insulin sensitivity due to an increase in lipolysis in the body which would produce free fatty acids. Free fatty acids in large quantities would affect the activity of insulin receptors, so insulin receptors could not work properly and would cause a decrease in insulin sensitivity. The level of insulin sensitivity was measured using an insulin tolerance test which was stated by the constant insulin tolerance test $\left(\mathrm{C}_{\text {IтT }}\right)$. The higher the value of $\mathrm{C}_{\text {IтT }}$, the better insulin sensitivity. Changes in $\mathrm{C}_{\text {IтT }}$ values during the induction and treatment period could be seen in Table-5. 
Table-5: Values of $\mathrm{C}_{\text {ITT }}$ in Insulin Tolerance Animal Model

\begin{tabular}{lcccc}
\hline \multirow{2}{*}{\multicolumn{1}{c}{ Group }} & \multicolumn{4}{c}{$\mathbf{C}_{\text {ITT }}$ Value } \\
\cline { 2 - 5 } & $\begin{array}{c}\text { Before } \\
\text { induction }\end{array}$ & $\begin{array}{c}\text { After 14 days } \\
\text { induction }\end{array}$ & $\begin{array}{c}\text { After 14 days } \\
\text { therapy }\end{array}$ & $\begin{array}{c}\text { Change of C } \\
\text { ITT } \\
\text { value (\%) }\end{array}$ \\
\hline Negative control & $1.90 \pm 0.85$ & $2.40 \pm 0.37$ & $2.04 \pm 0.42$ & $-15 \%$ \\
Positive control & $1.90 \pm 0.24$ & $0.46 \pm 0.61 \#$ & $0.56 \pm 0.34 \# @$ & $22 \%$ \\
Metformin 65 mg/kg bw & $2.09 \pm 0.44$ & $1.09 \pm 0.33 \#$ & $1.94 \pm 0.25$ & $78 \%$ \\
OFE 25 mg/kg bw & $2.32 \pm 0.66$ & $1.11 \pm 0.29 \#$ & $1.28 \pm 0.79 \#$ & $15 \%$ \\
OFE 50 mg/kg bw & $2.66 \pm 0.30$ & $0.84 \pm 0.71 \#$ & $1.38 \pm 0.15 *$ & $64 \%$ \\
OFE 100 mg/kg bw & $1.71 \pm 0.64$ & $1.03 \pm 0.63 \#$ & $1.76 \pm 0.56 *$ & $71 \%$ \\
OFE 200 mg/kg bw & $2.27 \pm 1.38$ & $0.89 \pm 0.41 \#$ & $1.02 \pm 0.45 \# @$ & $14 \%$ \\
\hline
\end{tabular}

Note : Data are presented as mean \pm SD, \# means significantly different compared to negative control group; * means significantly different compared to positive control group; @ means significantly different compared to metformin group; OFE means okra fruit extract, $\mathrm{p}<0.05, \mathrm{n}=5$ mice/group.

Based on the $\mathrm{C}_{\text {ITT }}$ value, the induction and treatment process gave a change in the level of insulin sensitivity. Administration of fat emulsion for 14 days could reduce insulin sensitivity, this can be seen from the $\mathrm{C}_{\text {IтT }}$ value before and after induction. At the time before induction, all groups showed homogeneous $\mathrm{C}_{\text {Ітт }}$ values and no significant differences $(\mathrm{P}>0.05)$ between groups. This value was used as the baseline of the level of insulin sensitivity during the experiment. While after 14 days of induction, the $\mathrm{C}_{\text {IтT }}$ values in all induced groups experienced a significant decrease $(\mathrm{p}<0.05)$ compared to the negative control group. These mean that insulin sensitivity in induced animal groups had decreased.

After 14 days of therapy, the $\mathrm{C}_{\text {IтT }}$ value from the positive control group still showed a significant difference $(\mathrm{P}<0.05)$ with negative controls. This mean that at the end of the study the positive control group still had a low level of insulin sensitivity. While the group given treatment either by metformin as a standard drug or okra fruit juice experienced an increase in insulin sensitivity. The highest increase in insulin sensitivity as much as 1.94 was shown by the metformin group. Metformin as a standard drug used in the treatment of diabetes had a mechanism of action to increase insulin sensitivity. All groups were given okra fruit juice at doses of $25,50,100$, and $200 \mathrm{mg} / \mathrm{kg}$ bw increased the C СтT value to 1.28 , $1.38,1.76$, and 1.02, respectively. Although statistically only 50 and $100 \mathrm{mg} / \mathrm{kg}$ bw of okra fruit juice had a significant difference $(\mathrm{p}<0.05)$ compared with positive controls and not significantly different than the metformin group. It showed that at this dose, okra fruit juice has activity in increasing insulin sensitivity.

\section{Alpha Glucosidase and Alpha Amylase Inhibitory Activity}

Evaluation of alpha glucosidase inhibitory activity was carried out at several sample concentrations; for acarbose, 3 concentration variations were made: $5 \mu \mathrm{g} / \mathrm{mL}, 10 \mu \mathrm{g} / \mathrm{mL}$, and $15 \mu \mathrm{g} / \mathrm{mL}$, while okra fruit extract used 6 concentrations: $50 \mu \mathrm{g} / \mathrm{mL}, 100 \mu \mathrm{g} / \mathrm{mL}, 150 \mu \mathrm{g} / \mathrm{mL}, 200 \mu \mathrm{g} / \mathrm{mL}, 150 \mu \mathrm{g} / \mathrm{mL}$, and 300 $\mu \mathrm{g} / \mathrm{mL}$. The inhibition activity of $\alpha$-glucosidase enzyme from acarbose and okra fruit extract can be seen in Fig.-2 and Fig.-3, respectively.

Figure- 2 and 3 showed that the higher the concentration, the higher the inhibition of alpha glucoside enzymes. This was because at high concentrations there were more solutes in the form of secondary metabolites from plants that had the ability to inhibit the action of the $\alpha$-glucosidase enzyme. From the equations obtained in the graph from Figure 3 and 4, it was also known the $\mathrm{IC}_{50}$ value of acarbose and okra fruit extract. $\mathrm{IC}_{50}$ or inhibition concentration 50 is a sample concentration that can inhibit enzyme activity by $50 \%$. The smaller the $\mathrm{IC}_{50}$ value, the stronger the inhibitory activity. The $\mathrm{IC}_{50}$ acarbose value obtained from this experiment was $44.374 \mu \mathrm{g} / \mathrm{mL}$, while okra fruit extract was $1533.742 \mu \mathrm{g} / \mathrm{mL}$. This significantly different $\mathrm{IC}_{50}$ value indicates that okra fruit water extract had no activity in inhibiting the enzyme $\alpha$-glucosidase by using in vitro method. 
The inhibition activity of $\alpha$-amylase could be measured using in vitro method by hydrolyzing starch by the $\alpha$-amylase enzyme. This process was characterized by using iodine, which gave blue color when reacting with starch. The intensity of the blue indicates the starch contained in the mixture. If a sample had an $\alpha$-amylase enzyme inhibitory activity, then the intensity of blue would be stronger. In other words, the intensity of blue would be directly proportional to the $\alpha$-amylase enzyme inhibitory activity. The inhibition activity of alpha amylase enzyme from acarbose and okra fruit extract could be seen in Figure4 and 5 respectively.

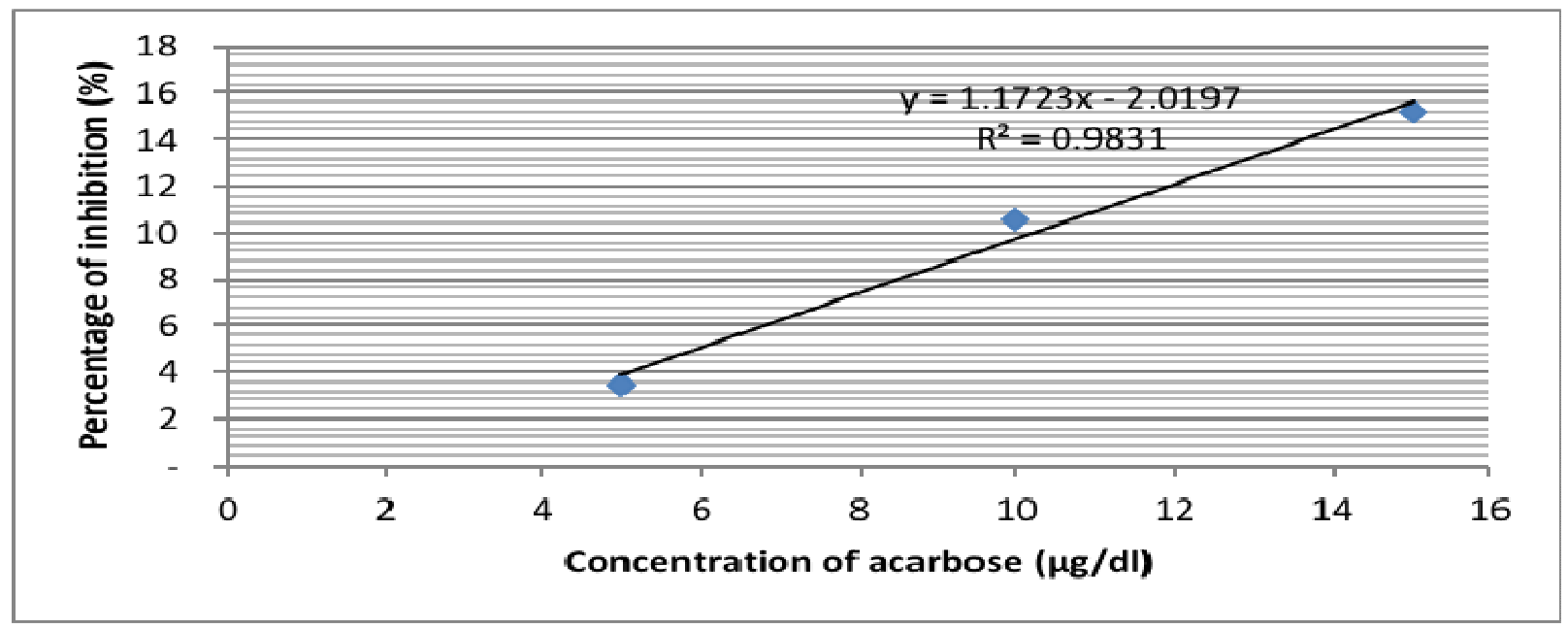

Fig.-2: Alpha Glucosidase Enzyme Inhibition Activity of Acarbose

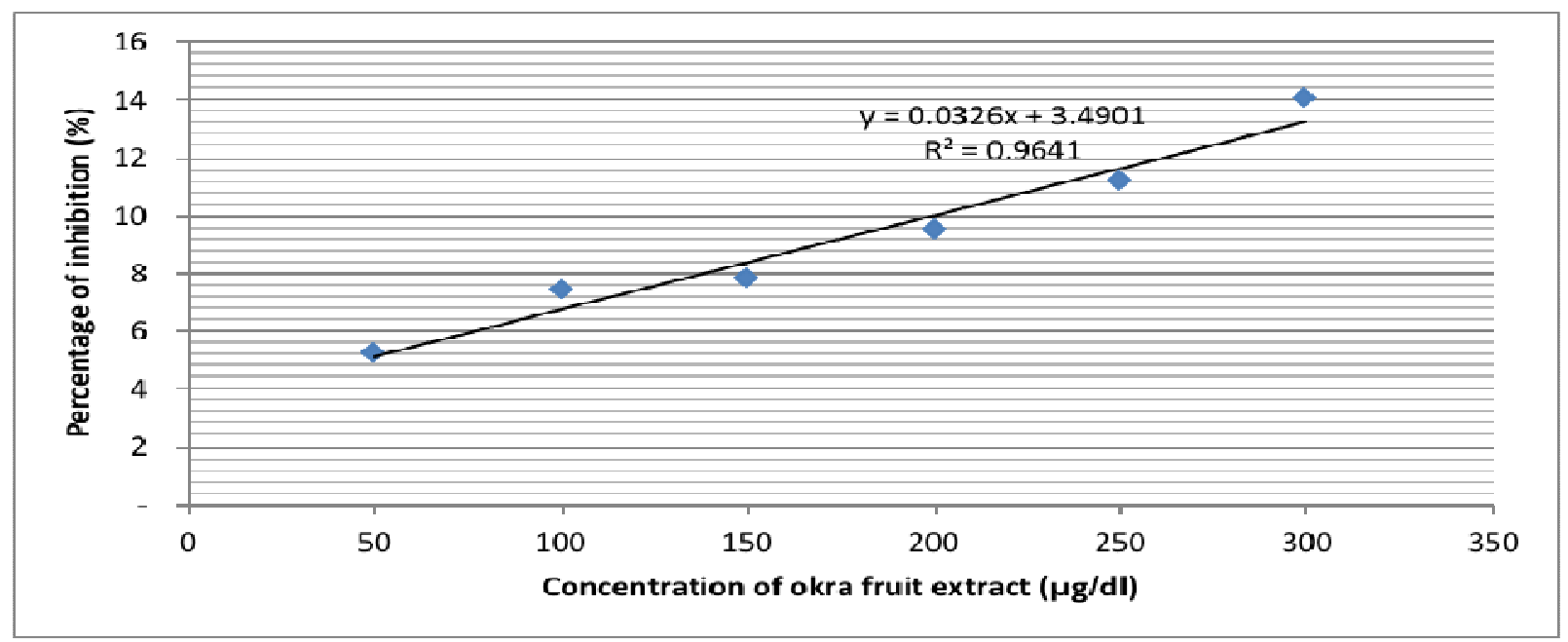

Fig.-3: Alpha Glucosidase Enzyme Inhibition Activity of Okra Fruit Extract

As with the results of evaluating the alpha glucosidase enzyme inhibitory activity, the increase in sample concentration was proportional to the increase in the inhibitory activity of the alpha amylase enzyme. The $\mathrm{IC}_{50}$ value of acarbose to alpha amylase enzyme was $46.821 \mu \mathrm{g} / \mathrm{mL}$, while okra fruit extract was $1228.469 \mu \mathrm{g} / \mathrm{mL}$. Based on the $\mathrm{IC}_{50}$ values, it could be concluded that okra fruit extract had no activity as an inhibitor of $\alpha$-amylase enzymes.

Antidiabetic effects in insulin deficiency and insulin resistance animal models showed by okra fruit juice were related to their chemical compounds. Based on phytochemical screening, it was known that okra fruit juice contained flavonoids and steroids / triterpenoids. Polyphenols could modulate carbohydrate and lipid metabolism, attenuate hyperglycemia, dyslipidemia and insulin resistance, improve adipose tissue metabolism, and alleviate oxidative stress and stress-sensitive signaling pathways and inflammatory processes $^{25}$. While triterpenoids have strong antioxidant activity and inhibit the formation of advanced 
RASĀYAN J. Chem.

Vol. 12 | No. 1 |157 - 167| January - March | 2019

glycation end products, implicated in the pathogenesis of diabetic nephropathy, embryopathy, neuropathy or impaired wound healing ${ }^{26}$. In addition to these compounds, from previous studies, it was said that the chemical compounds of okra fruit which had antidiabetic effects were $\alpha$-cellulose and hemicellulose which was fiber groups, where fiber can help stabilize blood sugar levels by limiting the absorption of sugar in the intestinal tract ${ }^{12}$. This was in line with the evaluation results where an increase in blood glucose level after administration of sucrose or starch was significantly lower compared to the group not administered okra fruit extract.

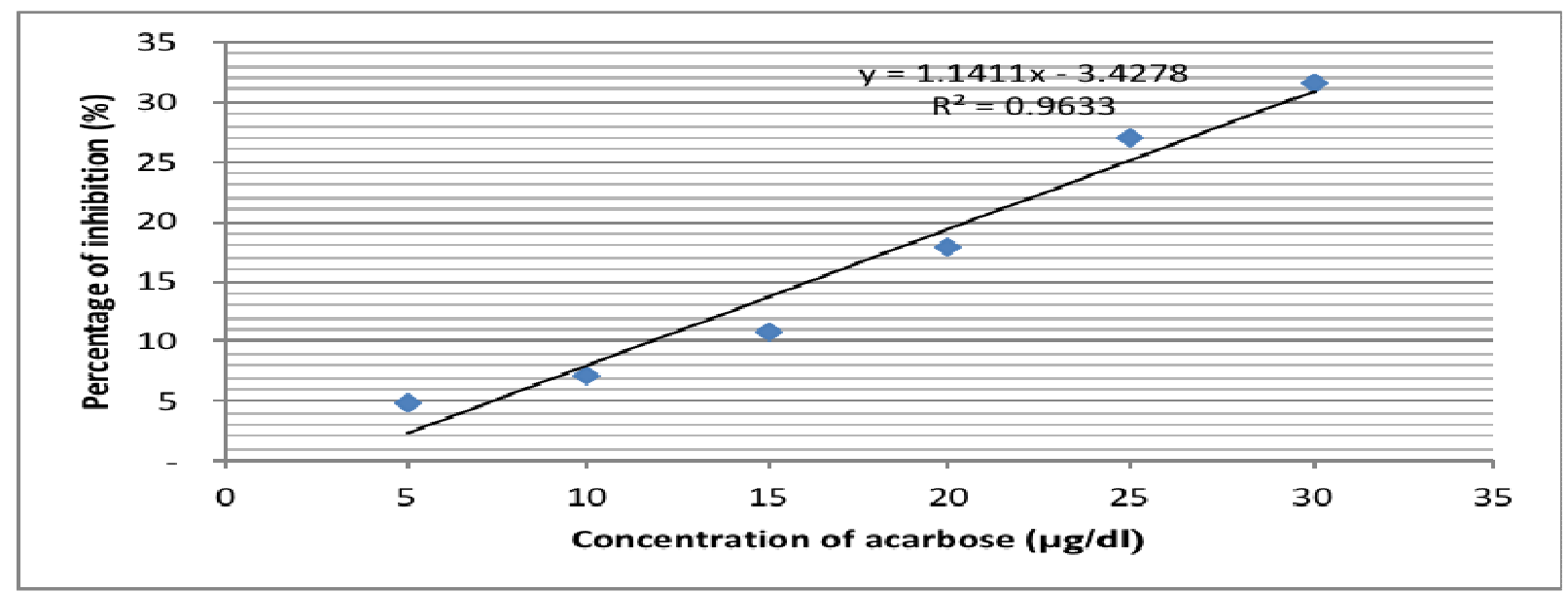

Fig.-4: Alpha Amylase Enzyme Inhibition Activity of Acarbose

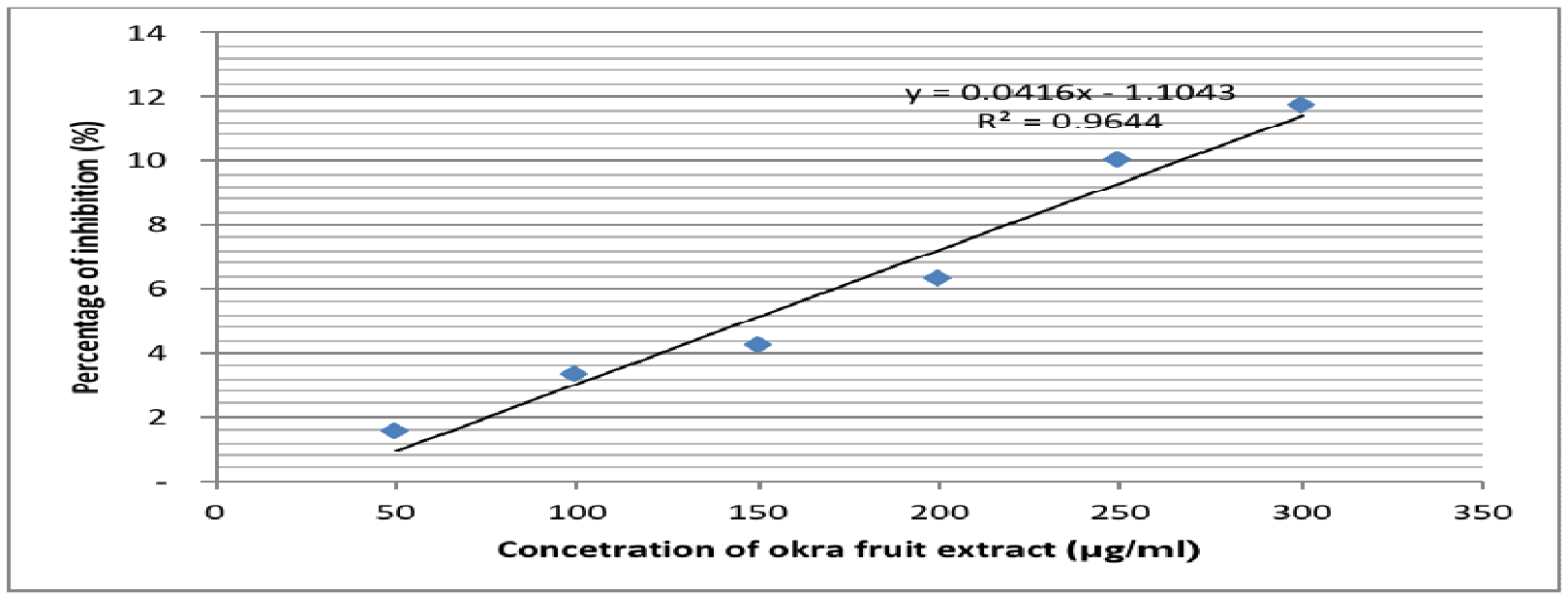

Fig.-5: Alpha Amylase Enzyme Inhibition Activity of Okra Fruit Extract

\section{CONCLUSION}

Okra (Abelmoschus esculentus L.) fruit extract with a dose of $50 \mathrm{mg} / \mathrm{kg}$ bw had the antidiabetic activity with the mechanism of action by increasing insulin secretion, increasing insulin sensitivity, and inhibiting carbohydrate absorption in the intestine; but showed no effect in inhibiting alpha glucosidase and alpha amylase enzyme.

\section{ACKNOWLEDGMENT}

This research was fully supported by The Ministry of Research, Technology, and the Higher Education Republic of Indonesia through the Research of Inter-university Cooperation scheme in 2018.

\section{REFERENCES}

1. B.G. Wells, J.T. Dipiro, T.L. Schwinghammer, and C. Dipiro, Pharmacotherapy Handbook 9/E, McGraw-Hill Education, New York (2014). 
RASĀYAN J. Chem.

Vol. 12 | No. 1 |157 - 167| January - March | 2019

2. International Diabetes Federation, IDF Diabetes Atlas, International Diabetes Federation, Belgia (2015).

3. American Diabetes Association, 38 (Suppl. 1), S8-16 (2015), DOI:10.2337/dc15-S005

4. American Diabetes Association, Diabetes Care, 38 (Suppl. 1), S8-16 (2015), DOI:10.2337/dc15S001

5. P. Palsamy and S. Subramanian, Biomed. Pharmacother., 62(9), 598(2008), DOI: 10.1016/j.biopha.2008.06.037

6. G. Shui and L.L. Peng, Journal of Chromatography A, 1048, 17(2004), DOI: 10.1016/j.chroma.2004.07.032

7. S.E. Atawodi, J.C. Atawodi, G.A. Idakwo, B. Pfundstein, R. Haubner, G. Wurtel, Spiegelhalder and R.W. Owen, J. Med. Food, 12(6), 1316(2009), DOI: 10.1089/jmf.2008.0211

8. G. Haro, I. Iksen, R.M. Rumanti, N. Marbun, R.P. Sari, R.P.J. Gultom, Rasayan Journal of Chemistry, 11(1), 232(2018), DOI: 10.7324/RJC.2018.1112011

9. N. Nerdy, K. Manurung, Rasayan Journal of Chemistry, 11(3), 1183(2018), DOI: 10.31788/RJC.2018.1134018

10. N.M. Ansari, L. Houlihan, B. Hussain, A. Pieroni, Phytotherapy Research, 19(10), 907(2005), DOI: 10.1002/ptr.1756

11. H. Liao, H. Liu and K. Yuan, Pharmagnosy Magazine, 8, 12(2012), DOI: 10.4103/0973-1296.93303

12. E. Abi, I. Abi and M.J. Ladan, Endocrinol Diabetes Res., 3(1), (2017), DOI: 10.4172/24707570.1000118

13. V. Sabitha, S. Ramachandran, K.R. Naveen, and K. Panneerselvam, J. Pharm. Bioallied. Sci., 3(3), 397(2011), DOI: 10.4103/0975-7406.84447

14. N. Mishra, D. Kumar, S.I. Rizvi, Journal of Dietary Supplements, 13(6), 540, 634 (2016), DOI: $10.3109 / 19390211.2016 .1164787$

15. C. Lengsfeld, F. Titgemeyer, G. Faller and A. Hensel, J. Agric. Food Chem., 52,1495(2004), DOI: 10.1021/jf030666n

16. J. Messing, C. Thöle, M. Niehues, A. Shevtsova, E. Glocker and A. Hensel, PLoS One, 9(1) (2014), DOI:10.1371/journal.pone.0084836

17. S. Ramesh, J.S. Sudarsan, M. Jothilingam, Rasayan Journal of Chemistry, 9(3), 325(2016).

18. V. Maithili, S.P. Dhanabal, S. Mahendran and R. Vadivelan, Indian Journal of Pharmacology, 43(4), 455(2011), DOI:10.4103/0253-7613.83121

19. W. Aligita, E. Susilawati, I.K. Sukmawati, L. Holidayanti, J. Riswanti, The Indonesian Biomedical Journal, 10(2), 165(2018), DOI: 10.18585/inabj.v10i2.405

20. B. Elya, K. Basah, A. Mun'in, W. Yuliastuti, A. Bangun and E. Septiana, Journal of Biomedicine and Biotechnology, 2012, 281078 (2012), DOI: 10.1155/2012/281078

21. Z. Xiao, R. Storms and A. Tsang, Anal. Biochem., 351(1), 146(2006), DOI: 10.1016/j.ab.2006.01.036

22. J. S. Dunn, H. L. Sheehan and N. G. B. Mclethie, Lancet., 241(6242), 484(1943), DOI: 10.1016/S0140-6736(00)42072-6

23. N. Dhanesha, A. Joharapurkar, G. Shah, V. Dhote, S. Kshirsagar, R. Bahekar, and M. Jain, J. Diabetes., 4(4), 369(2012), DOI: 10.1111/j.1753-0407.2012.00193.x.

24. S. Lenzen, Diabetologia, 51(2), 216(2008), DOI: 10.1007/s00125-007-0886-7

25. R. Testa, A.R. Bonfigli, S. Genovese, V.D. Nigris, and A. Ceriello, Nutrients, 8(5), 310 (2016), DOI: $10.3390 /$ nu 8050310

26. J. Nazaruk and M. Borzym-Kluczyk, Phytochem. Rev., 14(4), 675(2015), DOI: 10.1007/s11101014-9369-x

[RJC-5059/2018] 